\title{
THE RELATIONSHIP BETWEEN THE UNDERSTANDING OF INDONESIAN NATIONAL HISTORY, HISTORY LEARNING INTEREST, AND HISTORY AWARENESS AND THE NATIONALISM ATTITUDE.
}

\author{
Cintatia Salsabila, Aman \\ PPS Universitas Negeri Yogyakarta, Universitas Negeri Yogyakarta \\ Email: Cintatiasalsabila24@gmail.com, aman@uny.ac.id
}

\begin{abstract}
Abstrak
Penelitian ini bertujuan untuk mendeskripsikan hubungan pemahaman sejarah nasional Indonesia, minat belajar sejarah, kesadaran sejarah dengan sikap nasionalisme. Uji hipotesis terdiri dari korelasi Pearson Product Moment, korelasi ganda, sumbangan relatif, dan sumbangan efektif. Prasyarat analisis terdiri dari uji normalitas, uji linearitas dan uji multikolinearitas. Uji hipotesis terdiri dari korelasi Pearson Product Moment, korelasi ganda, sumbangan relatif, dan sumbangan efektif. Hasil penelitian menunjukan bahwa: (1) terdapat hubungan positif dan signifikan antara pemahaman sejarah nasional Indonesia dan sikap nasionalisme, (2) terdapat hubungan positif dan signifikan antara minat belajar sejarah dengan sikap nasionalisme, (3) terdapat hubungan positif dan signifikan antara kesadaran sejarah dengan sikap nasionalisme, (4) terdapat hubungan positif dan signifikan secara bersamaan antara pemahaman sejarah nasional Indonesia, minat belajar sejarah dan kesadaran sejarah dengan sikap nasionalisme.
\end{abstract}

Kata Kunci: Pemahaman sejarah nasional Indonesia, Minat belajar sejarah, kesadaran sejarah, sikap nasionalisme

\begin{abstract}
This study aimed to find out the relationship between the understanding of Indonesian national history, the history learning interest, the relationship between the history awareness and the nationalism attitude. Tests of analysis assumptions consisted of tests of normality, linearity, and multicollinearity. The hypotheses were tested using Pearson's product moment correlation and multiple correlation with relative and effective contributions. The results of the study show that: (1) there is a significant positive relationship between the understanding of Indonesian national history and the nationalism attitude, (2) there is a significant positive relationship between the history learning interest and the nationalism attitude, (3) there is a significant positive relationship between the history awareness and the nationalism attitude, (4) there is a significant positive relationship between the understanding of Indonesian national history, history learning interest, and history awareness as an aggregate and the nationalism attitude.
\end{abstract}

\section{Keyword: understanding of Indonesian national history, history learning interest, history awareness, nationalism attitude}

\section{Pendahuluan}

Indonesia merupakan salah satu Negara yang memiliki beragam budaya. Selain itu Indonesia juga memiliki sejarah bangsa yang panjang. Menjadi sebuah keironisan jika banyak orang yang kehilangan perasaan cinta tanah air. Fakta yang ada sekarang ini terutama di kalangan generasi muda, nilai kecintaan kepada tanah air semakin berkurang. 
Menurut survei Badan Pusat Statistik dari 100 orang Indonesia terdapat 18 orang yang tidak tahu judul lagu kebangsaan Republik Indonesia. Kemudian 24 orang dari 100 orang di Indonesia tidak hafal sila-sila Pancasila dan 53 persen orang Indonesia tidak hafal lirik lagu kebangsaan (http://www.merdeka.com).

Perkembangan dan kemajuan zaman yang begitu pesat mengakibatkan memudarnya batas-batas suatu kewilayahan yang sering dikenal sebagai globalisasi. Setiap Negara di dunia siap tidak siap harus menerima setiap perubahan yang ada. Hal ini pun berlaku untuk Negara Indonesia yang harus mengikuti perubahan dan menyesuaikan diri agar dapat tetap hidup sejalan dengan adanya arus perubahan sebagai salah satu warga dunia yang berinteraksi di tengah-tengah aktivitas masyarakat dunia. Hal ini yang diduga dapat melunturkan rasa nasionalisme.

Sikap nasionalisme diperlukan dalam perkembangan pendidikan siswa di sekolah yang berbasis kepada mentalitas warga negara. Sehingga bisa dijadikan sebagai fondasi bangsa yang mampu menguatkan sendi-sendi bangsa di tengah gencarnya proses globalisasi yang melanda seluruh pelosok negeri. Pengaruh globalisasi di kalangan remaja khususnya pelajar, membuat yang tidak siap menjadi kehilangan identitas kebangsaan. Hal ini yang menyebabkan nasionalisme di kalangan siswa menjadi luntur. Penyeragaman kebudayaan yang ada pada era saat ini pada akhirnya menggeser identitas yang dimiliki oleh setiap bangsa. Lunturnya identitas sebuah bangsa mengisyaratkan bahwa akan terancamnya keberadaan jati diri sebuah bangsa tersebut.

Nasionalisme adalah semacam ideologi berdasarkan emosi nasional hal ini merupakan cinta dan kesetiaan dari para warga negara bagi bangsa sendiri, termasuk warisan dan pemeliharaan oleh warga negara seperti adat istiadat, hukum, memori, bahasa, seni dan ekspresi keagamaan, sistem sosial umum nasional dan gaya hidup (Zhang, 2014: 65).

Sikap nasionalisme adalah perwujudan adanya rasa bangga, setia dan cinta tanah air dari seseorang serta senantiasa mempertahankan dan memajukan bangsa dan negaranya. Perwujudan sikap nasionalisme bisa dilakukan dalam berbagai hal dan di mana saja sebab nasionalisme bukan pembawaan manusia sejak lahir, melainkan sebagai hasil peradaban manusia dalam menjawab tantangan hidupnya. Sikap nasionalisme menjadi sangat penting sebab bangsa Indonesia merupakan bangsa yang besar dengan bermacam-macam suku, agama, ras maupun budaya.

Namun konsep nasionalisme Indonesia menurut Soewarsono (2011: 97) seiring berjalannya waktu mulai terdapat penyesuaian-penyesuaian, namun tetap pada hakikat nasionalisme yang sama yaitu sebuah persatuan dan kesatuan. Nasionalisme saat ini tidak lagi diasumsikan sebagai nasionalisme klasik oleh generasi baru yang memiliki konsep cinta pada tanah air yang ada di zaman Soekarno tahun-50an di mana melarang seluruh tanah bangsa diinjak oleh bangsa lain. Menurut (Sudarsono, 2011: vii) generasi baru sekarang ini mulai memikirkan bagaimana memaknai nasionalisme berdasarkan cara yang sesuai dengan perkembangan zaman.

Berdasarkan hasil observasi di beberapa sekolah yang dijadikan sebagai tempat penelitian masih sering dijumpai sejumlah masalah yang terkait dengan sikap nasionalisme siswa. Sikap siswa yang menjadi masalah terkait sikap nasionalisme adalah dalam kehidupan sehari-hari yaitu dengan mengikuti gaya hidup orang barat seperti bangga menggunakan produk keluaran barat daripada produk dalam negeri kemudian ketika melaksanakan upacara banyak 
siswa yang masih berbicara sendiri seharusnya siswa mengikuti upacara dengan baik dan khidmat atas dorongan diri sendiri sebab paham bagaimana perjuangan para pahlawan merebut bangsa Indonesia dari penjajah.

Aktivitas generasi muda saat ini telah mengalami perubahan seiring dengan adanya globalisasi dan kemajuan teknologi. Setiap Negara di dunia siap tidak siap harus menerima setiap perubahan yang ada. Hal ini pun berlaku untuk Negara Indonesia yang harus mengikuti perubahan dan menyesuaikan diri agar dapat tetap hidup sejalan dengan adanya arus perubahan sebagai salah satu warga dunia yang berinteraksi di tengah-tengah aktivitas masyarakat dunia. Teknologi yang berkembang pesat menyebabkan penurunan moral dan sikap dari bangsa Indonesia. Melalui berbagai media yang tersedia, masyarakat dengan mudah mampu mengakses apa pun tanpa menyaring terlebih dahulu mana yang sesuai dengan budaya bangsa Indonesia dan mana yang tidak sejalan dengan budaya Indonesia. Hal ini yang diduga dapat melunturkan rasa nasionalisme. Berdasarkan uraian di atas menarik untuk diteliti hubungan antara pemahaman sejarah nasional Indonesia, minat belajar sejarah dan kesadaran sejarah dengan sikap nasionalisme.

Kesadaran sejarah mencakup setiap bentuk atau kegiatan pemikiran tentang masa lalu dari sebuah studi sejarah hingga penggunaannya dan fungsi sejarah itu sendiri dalam kehidupan pribadi dan umum. Kesadaran sejarah berkaitan dengan pengalaman sebelumnya yang mengungkapkan perubahan temporal di mana kehidupan di masa lalu dan perspektif masa depan menuju perubahan yang akan terjadi (Clark, 2014: 88).

Memiliki kesadaran sejarah akan membuat sebuah bangsa tidak akan kehilangan nilai-nilai yang sangat dibutuhkan di mana pun dalam keadaan bagaimanapun. Nilai-nilai terebut ialah nasionalisme patriotisme demokratis dan lain sebagainya (Latif, 2011: 51).

Minat memiliki peranan dalam proses pembelajaran yaitu untuk memusatkan pemikiran dan menimbulkan kegembiraan dalam sebuah usaha belajar. minat mampu mendorong seseorang untuk memperhatikan orang atau sesuatu dan hal itu berlaku untuk siswa yang minat pada pembelajaran sejarah. Minat dapat menghasilkan sikap yang merupakan suatu kesiapan berbuat bila ada stimulus khusus sesuai dengan keadaan yang ada.

Minat mengandung unsur-unsur yang terdiri dari kognisi (mengenal), emosi (perasaan), dan konasi (kehendak). Unsur kognisi, dalam arti minat itu didahului oleh pengetahuan dan informasi mengenai objek yang dituju oleh minat tersebut. Unsur emosi karena dalam partisipasi atau pengalaman itu disertai dengan perasaan tertentu (perasaan senang) sedangkan unsur konasi merupakan kelanjutan dari kedua unsur tersebut yaitu yang diwujudkan dalam bentuk kemauan dan hasrat untuk melakukan suatu kegiatan (Ahmadi, 2013: 151).

Minat belajar sejarah merupakan rasa senang dan tertarik dalam mempelajari pelajaran sejarah serta memiliki perhatian yang tinggi yang dapat membantu seseorang dalam memahami pelajaran sejarah yang mengandung semangat berbangsa dan bertanah air. Siswa yang berminat terhadap pelajaran sejarah akan mengikuti pembelajaran sejarah dengan senang dan bersungguh-sungguh sebab hal tersebut datang dari dalam diri siswa itu sendiri yang didasarkan oleh rasa suka dan tidak adanya paksaan dari pihak lain.

Pemahaman adalah proses yang menjadikan suatu pengetahuan menjadi milik dirinya dan pada akhirnya akan 
mempengaruhi proses berpikir dan bertindak individu (Arikunto (2009: 18). Pemahaman mencakup kemampuan untuk menangkap makna dan arti dari bahan yang dipelajari.

Poesponegoro \& Notosusanto (2010: jilid I-VI) membagi sejarah nasional Indonesia berdasarkan kurun waktu yaitu zaman prasejarah, aman kuno (awal masehi-1500 M), zaman pertumbuhan dan perkembangan kerajaan Islam di Indonesia (1500-1800 M), kemunculan penjajahan di Indonesia, zaman kebangkitan nasional dan zaman masa akhir Hindia Belanda hingga zaman Jepang dan Republik. Meskipun sejarah nasional Indonesia dibatasi pada wilayah bekas jajahan Hindia Belanda pada masa kolonial, namun sejarah Indonesia bukan berarti baru dimulai ketika dijajah. Kesatuan akan senasib penjajahan dan konsensus untuk kemerdekaan diri, memberikan konsekuensi logis bahwa masa lalu wilayah disatukan kini menjadi masa lalu kolektif sebuah bangsa Indonesia.

Pemahaman sejarah nasional Indonesia adalah suatu proses kemampuan dalam menangkap makna dan penguasaan terhadap materi-materi yang dipelajari mengenai sejarah nasional Indonesia dengan benar serta mempengaruhi proses berpikir serta bertindak individu. Kemampuan memahami menjadi sebuah bagian penting untuk siswa dalam memaknai hal-hal yang dipelajari. Tanpa hal tersebut maka pengetahuan yang diharapkan tidak akan bermakna.

Menanamkan pemahaman tentang masa lampau bangsa Indonesia adalah salah satu tujuan dalam pembelajaran sejarah di sekolah. Siswa perlu diberikan pemahaman tentang sejarah bangsa Indonesia untuk menumbuhkan sikap nasionalisme melalui penghayatan nilai masa lampau bangsa kita (Tugiyono, 2004: 5-6)
Sejumlah permasalahan yang ditemukan dalam penelitian ini yaitu: (1) kurang optimalnya pembelajaran sejarah, (2) siswa tidak aktif, inovatif dan kritis serta kurang menanggapi materi sejarah yang disampaikan oleh guru, (3) sejarah masih terdengar mempunyai gambaran buruk yang melekat dalam sejarah, misalnya adalah sejarah yang berupa kumpulan fakta yang semua tidak menyadari nilai gunanya dalam kehidupan (4) menurunnya sikap nasionalisme karena berbagai pengaruh dari globalisasi, penyeragaman budaya, dan perkembangan iptek.

Penelitian ini bertujuan untuk mengetahui: (1) hubungan pemahaman sejarah nasional Indonesia dengan sikap nasionalisme, (2) hubungan minat belajar sejarah dengan sikap nasionalisme, (3) hubungan kesadaran sejarah dengan sikap nasionalisme, (4) hubungan pemahaman sejarah nasional Indonesia, minat belajar sejarah dan kesadaran sejarah secara bersama-sama dengan sikap nasionalisme.

\section{Metode Penelitian}

Penelitian ini menggunakan pendekatan penelitian kuantitatif dengan jenis penelitian korelasional. Penelitian ini menekankan pada pengukuran variabel dengan angka dan melakukan analisis data dengan prosedur statistik dengan menggunakan analisis korelasi product moment dan korelasi ganda.

Penelitian dilaksanakan di SMA Negeri 1 Godean, SMA 1 Prambanan, dan SMA 1 Gamping yang terletak di kabupaten Sleman. Populasi dalam penelitian ini adalah siswa di tiga sekolah tersebut sebanyak 199, dengan menggunakan perhitungan rumus dari Isacc dan Michael didapatkan sampel sebanyak 132.

Variabel bebas dalam penelitian ini adalah pemahaman sejarah nasional Indonesia, minat belajar sejarah dan kesadaran sejarah. Variabel terikat yang 
digunakan dalam penelitian ini adalah sikap nasionalisme. Pemahaman sejarah nasional Indonesia adalah Pemahaman sejarah nasional Indonesia adalah suatu proses kemampuan dalam menangkap makna dan penguasaan terhadap materimateri yang dipelajari mengenai sejarah nasional Indonesia dengan benar serta mempengaruhi proses berpikir serta bertindak individu. Pemahaman sejarah nasional Indonesia yang dimaksud dalam penelitian ini adalah kemampuan siswa dalam menyelesaikan soal mengenai sejarah nasional Indonesia yang dibagi dalam beberapa bagian.

Minat belajar sejarah adalah Minat belajar sejarah merupakan rasa senang dan tertarik dalam mempelajari pelajaran sejarah serta memiliki perhatian yang tinggi yang dapat membantu seseorang dalam memahami pelajaran sejarah yang mengandung semangat berbangsa dan bertanah air. Siswa yang berminat terhadap pelajaran sejarah akan mengikuti pembelajaran sejarah dengan senang dan bersungguh-sungguh sebab hal tersebut datang dari dalam diri siswa itu sendiri yang didasarkan oleh rasa suka dan tidak adanya paksaan dari pihak lain.

Kesadaran sejarah adalah sebuah kondisi yang mengetahui tentang peristiwa-peristiwa sejarah serta menunjukkan tingkat penghayatan pada makna dan hakikat sejarah bagi masa kini dan yang akan datang dalam menghadapi tantangan ke depannya dalam menjaga peninggalan sejarah bangsa. Kesadaran sejarah di sekolah diharapkan mampu menyadarkan siswa mengenai adanya proses perubahan dan perkembangan masyarakat dalam dimensi waktu.

Variabel terikat dalam penelitian ini adalah sikap nasionalisme. Sikap nasionalisme merupakan suatu sikap cinta tanah air atau bangsa dan negara sebagai wujud dari cita-cita dan tujuan kemerdekaan nasional dengan prinsip kebebasan dan kesamarataan kehidupan bermasyarakat dan bernegara. Sikap nasionalisme harus ditanamkan kepada para generasi bangsa terutama siswa baik pada segala aspek kehidupan.

Instrumen yang digunakan dalam penelitian ini adalah tes pemahaman sejarah nasional Indonesia, angket minat belajar sejarah, angket kesadaran sejarah dan angket sikap nasionalisme. Titik tolak penyusunan instrumen adalah definisi operasional variabel-variabel penelitian yang telah ditetapkan untuk diteliti. Berdasarkan definisi operasional tersebut, ditentukan indikator yang akan diukur. Indikator ini kemudian dijabarkan menjadi butir-butir pertanyaan atau pernyataan.

Komponen-komponen

dari variabel yang akan diteliti dijabarkan menjadi item-item instrumen. Item-item instrumen harus disusun dengan bahasa yang jelas sehingga semua pihak yang berkepentingan tahu apa yang dimaksud dalam item instrumen tersebut. Agar penyusunan instrumen dapat dilakukan dengan baik, berikut ditampilkan kisi-kisi instrumen penelitian.

Validitas instrumen menggunakan validitas isi dan konstruk. Validitas isi adalah dengan mengonsultasikan indikator-indikator yang akan diukur dan mencapai tujuan yang akan dicapai kepada expert judgment. Validitas konstruk dengan menggunakan rumus korelasi product moment.

Hasil validitas variabel pemahaman sejarah nasional Indonesia menunjukkan sebanyak 21 butir pertanyaan dinyatakan valid karena nilai korelasi $>0,254$, sehingga sejumlah butir pertanyaan tersebut dapat dijadikan sebagai instrumen penelitian. Hasil validitas variabel minat belajar sejarah menunjukkan sebanyak 20 butir pernyataan dinyatakan valid karena nilai korelasi $>0,254$, sehingga sejumlah butir pernyataan tersebut dapat dijadikan sebagai instrumen penelitian. 
Hasil validitas variabel kesadaran sejarah menunjukkan sebanyak 22 butir pernyataan dinyatakan valid karena nilai korelasi $>0,254$, sehingga sejumlah butir pernyataan tersebut dapat dijadikan sebagai instrumen penelitian. Hasil validitas variabel sikap nasionalisme menunjukkan sebanyak 23 butir pernyataan dinyatakan valid karena nilai korelasi $>0,254$, sehingga sejumlah butir pernyataan tersebut dapat dijadikan sebagai instrumen penelitian.

Pengujian reliabilitas dalam penelitian ini digunakan formula koefisien KR-21 dan Alpha. Instrumen dikatakan reliabel apabila memiliki koefisien keandalan atau reliabilitas sebesar 0,6 atau lebih. Hasil pengujian reliabilitas untuk instrumen pemahaman sejarah nasional Indonesia $\left(\mathrm{X}_{1}\right)$, minat belajar sejarah $\left(\mathrm{X}_{2}\right)$, kesadaran sejarah $\left(\mathrm{X}_{3}\right)$ dan sikap nasionalisme (Y) mempunyai nilai lebih besar dari 0,6, sehingga dapat disimpulkan bahwa semua instrumen yang dipergunakan reliabel.

Data yang terkumpul kemudian diolah dan dianalisis dengan teknik deskriptif dan uji persyaratan analisis serta uji hipotesis. Uji persyaratan analisis dilakukan agar hasil analisis memenuhi persyaratan analisis. Uji persyaratan analisis dalam penelitian ini meliputi uji normalitas, uji linieritas, dan uji multikolinieritas.

Uji normalitas data dilakukan dengan menggunakan KolmogorovSmirnov Test dan dilakukan dengan menggunakan program SPSS. Dengan pedoman pengambilan data apabila nilai Kolmogorov-Smirnov-Z lebih besar dari nilai kritis atau nilai $\mathrm{p}<0,05$, maka dapat diduga bahwa distribusi data adalah tidak normal.

Uji linieritas data dilakukan dengan menggunakan Uji koefisien $\mathrm{F}$ dan dilakukan dengan menggunakan program SPSS. Dengan pedoman pengambilan data apabila nilai $\mathrm{F}_{\text {hitung }}<$
$\mathrm{F}_{\text {tabel }}$ maka menunjukkan linier. Pengujian multikolinieritas dalam penelitian ini dilakukan untuk mengetahui apakah terdapat korelasi yang cukup besar antar variabel bebas. Apabila nilai Tolerance kurang dari 0,1 atau nilai VIF lebih dari 10 maka prediktor bersifat multikolinear.

Uji hipotesis dalam penelitian ini menggunakan korelasi product moment dan korelasi ganda. Analisis korelasi product moment digunakan untuk menguji hubungan variabel bebas secara individual terhadap variabel terikat, atau digunakan untuk menguji hipotesis pertama, kedua dan ketiga. Pengujian dilakukan dengan menggunakan bantuan program SPSS. Kriteria pengujian dalam penelitian ini adalah sebagai berikut: $\mathrm{H}_{\mathrm{o}}$ ditolak jika rhitung $>$ rtabel dan $p>0,05$.

\section{Hasil Penelitian dan Pembahasan}

Analisis Deskriptif

Nilai pemahaman sejarah nasional Indonesia diperoleh dari penyebaran soal tes dengan item sebanyak 21 dengan nilai 0 -1, sehingga nilai tertinggi ideal sebesar $21: 21 \times 100=100$. Berdasarkan rentang skor tersebut, maka mean ideal sebesar $100: 2=50,0$ dan standar deviasi ideal sebesar $100: 6=16,7$.

Tabel 1. Hasil Uji Kategorisasi Variabel Pemahaman Sejarah Nasional Indonesia

\begin{tabular}{ccccc}
\hline No & Skor & f & $\%$ & Kategori \\
\hline 1 & $>75,1$ & 23 & 17,4 & Sangat baik \\
2 & $58,4-$ & 62 & 47,0 & Baik \\
& 75,0 & & & \\
3 & $\begin{array}{c}41,8- \\
58,3\end{array}$ & 42 & 31,8 & Cukup baik \\
& $\begin{array}{c}5,3 \\
4\end{array}$ & $\begin{array}{c}25,1- \\
5\end{array}$ & 3,8 & Tidak baik \\
& 41,7 & & & \\
5 & $0-25$ & 0 & 100 & $\begin{array}{c}\text { Sangat } \\
\text { tidak baik }\end{array}$ \\
\hline & & & & \\
\hline
\end{tabular}

Sebagian besar responden mempunyai nilai pemahaman sejarah nasional Indonesia dalam kategori baik, yaitu 62 responden $(47,0 \%)$. Hal ini 
didukung dengan nilai rata-rata sebesar 62,93 menunjukkan bahwa pemahaman sejarah nasional Indonesia termasuk dalam kategori baik.

Skor minat belajar sejarah diperoleh dari penyebaran angket dengan item sebanyak 20 dengan skor 15 , sehingga nilai tertinggi ideal sebesar 20 $\mathrm{x} 5=100$. Berdasarkan rentang skor tersebut, maka mean ideal sebesar $120: 2$ $=60,0$ dan standar deviasi ideal sebesar $80: 6=13,3$.

Tabel 2. Hasil Uji Kategorisasi Variabel Minat Belajar Sejarah

\begin{tabular}{ccccc}
\hline No & Skor & F & $\%$ & Kategori \\
\hline 1 & $>80,1$ & 16 & 12,1 & Sangat baik \\
2 & $66,8-$ & 95 & 72,0 & Baik \\
& $\begin{array}{c}80,0 \\
53,4-\end{array}$ & 20 & 15,2 & Cukup baik \\
3 & $\begin{array}{c}5,7 \\
40,1-\end{array}$ & 1 & 0,8 & Tidak baik \\
4 & $\begin{array}{c}40,3 \\
4\end{array}$ & & & \\
5 & $0-40$ & 0 & 0 & Sangat \\
& & & & tidak baik \\
\hline & Total & 132 & 100 & \\
\hline
\end{tabular}

Sebagian besar responden mempunyai skor minat belajar sejarah dalam kategori baik, yaitu 95 responden $(72,0 \%)$. Hal ini didukung dengan nilai rata-rata sebesar 72,25 menunjukkan bahwa minat belajar sejarah termasuk dalam kategori baik.

Skor kesadaran sejarah diperoleh dari penyebaran angket dengan item sebanyak 22 dengan skor 1-5, sehingga nilai tertinggi ideal sebesar 22 x $5=110$. Berdasarkan rentang skor tersebut, maka mean ideal sebesar 132: $2=66,0$ dan standar deviasi ideal sebesar 88: $6=14,7$.

Tabel 3. Hasil Uji Kategorisasi Variabel Kesadaran Sejarah

\begin{tabular}{ccccc}
\hline No & Skor & f & $\%$ & Kategori \\
\hline 1 & $>88,1$ & 49 & 37,1 & Sangat baik \\
2 & $66,8-$ & 78 & 59,1 & Baik \\
& 80,0 & & &
\end{tabular}

\begin{tabular}{|c|c|c|c|c|}
\hline 3 & $\begin{array}{c}58,8- \\
66,7\end{array}$ & 4 & 3,0 & Cukup baik \\
\hline 4 & $\begin{array}{c}44,1- \\
58,7\end{array}$ & 1 & 0,8 & Tidak baik \\
\hline 5 & $0-44,0$ & 0 & 0 & $\begin{array}{c}\text { Sangat } \\
\text { tidak baik }\end{array}$ \\
\hline & Total & 132 & 100 & \\
\hline
\end{tabular}

Sebagian besar responden mempunyai skor kesadaran sejarah dalam kategori baik, yaitu 78 responden (59,1\%). Hal ini didukung dengan nilai rata-rata sebesar 86,88 menunjukkan bahwa kesadaran sejarah termasuk dalam kategori baik.

Skor sikap nasionalisme diperoleh dari penyebaran angket dengan item sebanyak 20 dengan skor 1-5, sehingga nilai tertinggi ideal sebesar $23 \times 5=115$. Berdasarkan rentang skor tersebut, maka mean ideal sebesar 138: $2=69,0$ dan standar deviasi ideal sebesar $92: 6=15,3$.

Tabel 4. Hasil Uji Kategorisasi Variabel Sikap Nasionalisme

\begin{tabular}{|c|c|c|c|c|}
\hline No & Skor & $\mathrm{F}$ & $\%$ & Kategori \\
\hline 1 & $>92,1$ & 58 & 58 & Sangat baik \\
\hline 2 & $\begin{array}{c}76,8- \\
92,0\end{array}$ & 71 & 71 & Baik \\
\hline 3 & $\begin{array}{l}61,2- \\
76,7\end{array}$ & 3 & 3 & Cukup baik \\
\hline 4 & $\begin{array}{c}46,1- \\
61,3\end{array}$ & 0 & 0 & Tidak baik \\
\hline 5 & $0-46,0$ & 0 & 0 & $\begin{array}{c}\text { Sangat } \\
\text { tidak baik }\end{array}$ \\
\hline & Total & 132 & 100 & \\
\hline
\end{tabular}

Sebagian besar responden mempunyai skor sikap nasionalisme dalam kategori baik, yaitu 71 responden $(53,8 \%)$. Hal ini didukung dengan nilai rata-rata sebesar 92,49 menunjukkan bahwa sikap nasionalisme termasuk dalam kategori baik.

Uji Prasyarat Analisis

Uji normalitas untuk mengetahui normal atau tidaknya distribusi data 
menggunakan Kolmogorov Smirnov. Membandingkan nilai probabilitas dengan nilai signifikansi yaitu 0,05.

Tabel 5. Hasil Uji Kolmogorov Smirnov

\begin{tabular}{cccc}
\hline Variabel & KS-Z & $\mathrm{P}$ & Ket \\
\hline $\mathrm{X}_{1}$ & 1,341 & 0,55 & Normal \\
$\mathrm{X}_{2}$ & 1,211 & 0,107 & Normal \\
$\mathrm{X}_{3}$ & 0,982 & 0,289 & Normal \\
$\mathrm{Y}$ & 0,978 & 0,295 & Normal \\
\hline
\end{tabular}

Berdasarkan hasil perhitungan di atas nilai $p$ pada variabel pemahaman sejarah nasional Indonesia sebesar 0,55 atau lebih besar dari 0,05 maka data untuk variabel tersebut mempunyai sebaran yang merata (normal). Nilai $\mathrm{p}$ pada variabel minat belajar sejarah sebesar 0,107 atau lebih besar dari 0,05 maka data untuk variabel tersebut mempunyai sebaran yang merata (normal). Nilai p pada variabel kesadaran sejarah sebesar 0,289 atau lebih besar dari 0,05 maka data untuk variabel tersebut mempunyai sebaran yang merata (normal). Nilai p pada variabel sikap nasionalisme sebesar 0,295 atau lebih besar dari 0,05 maka data untuk variabel tersebut mempunyai sebaran yang merata (normal).

Pedoman yang digunakan untuk menguji linieritas dengan jalan menguji signifikansi nilai F pada tabel F. Adapun hasil uji linieritas hubungan disajikan pada Tabel 6 .

Tabel 6. Hasil uji Linieritas

\begin{tabular}{cccc}
\hline Variabel & $\mathrm{F}$ & $\mathrm{P}$ & Ket \\
\hline $\mathrm{X}_{1}$ & 1,717 & 0,66 & Linier \\
$\mathrm{X}_{2}$ & 1,345 & 0,138 & Linier \\
$\mathrm{X}_{3}$ & 0,881 & 0,650 & Linier \\
\hline
\end{tabular}

Nilai p antara pemahaman sejarah nasional Indonesia (X1) dan sikap nasionalisme (Y) sebesar 0,66 atau lebih besar dari 0,05 maka hubungan antara kedua variabel tersebut linear. Nilai $p$ antara minat belajar sejarah (X2) dan sikap nasionalisme (Y) sebesar 0,138 atau lebih besar dari 0,05 maka hubungan antara kedua variabel tersebut linear. Nilai p antara kesadaran sejarah $\left(\mathrm{X}_{3}\right)$ dan sikap nasionalisme (Y) sebesar 0,650 atau lebih besar dari 0,05 maka hubungan antara kedua variabel tersebut linear.

Uji multikolinearitas bertujuan untuk mengetahui apakah terdapat korelasi yang cukup besar antar variabel bebas. Jika dalam model terdapat multikolinearitas maka model tersebut memiliki kesalahan standar yang besar sehingga koefisien tidak dapat ditaksir dengan ketepatan yang tinggi. Salah satu cara mendeteksi ada tidaknya multikolinearitas adalah dengan melihat nilai VIF.

Tabel 7. Hasil Uji Multikolineritas

\begin{tabular}{cccc}
\hline $\begin{array}{c}\text { Varia } \\
\text { bel }\end{array}$ & $\begin{array}{c}\text { Tolera } \\
\text { nce }\end{array}$ & VIF & Ket \\
\hline $\mathrm{X}_{1}$ & 0,830 & 1,205 & $\begin{array}{c}\text { Tidak } \\
\text { multikolineritas } \\
\text { Tidak }\end{array}$ \\
$\mathrm{X}_{2}$ & 0,783 & 1,278 & $\begin{array}{c}\text { multikolineritas } \\
\text { Tidak }\end{array}$ \\
$\mathrm{X}_{3}$ & 0,769 & 1,301 & $\begin{array}{c}\text { multikolineritas } \\
\text { m }\end{array}$ \\
\hline
\end{tabular}

Berdasarkan hasil perhitungan di atas nilai VIF pada variabel pemahaman sejarah nasional Indonesia sebesar 1,205 maka tidak ada gejala multikolinearitas. Nilai VIF pada variabel minat belajar sejarah sebesar 1,278 maka tidak ada gejala multikolinearitas. Nilai VIF pada variabel kesadaran sejarah sebesar 1,301 maka tidak ada gejala multikolinearitas.

Uji Hipotesis

Setelah tahap pengujian kualitas data yaitu menguji validitas dan reliabilitas instrumen dilakukan, maka selanjutnya pelaksanaan penelitian (pengambilan data) dilakukan. Se-telah data didapat, maka tahap selanjutnya ialah melakukan pengujian hipotesis. Dalam menguji hipotesis ini, maka digunakan uji parametric dengan mengguna-kan rumus korelasi Product 
moment dengan bantuan program perhitungan SPSS versi 22. Untuk dapat mengetahui kuat lemahnya tingkat atau derajat keeratan hubungan antara variabel-variabel yang diteliti, maka diguna-kan tabel kriteria pedoman untuk koefisien korelasi

Pengujian hipotesis dilaksanakan untuk membuktikan apakah hipotesis yang diajukan yang sifatnya sementara benar-benar terbukti atau tidak. Persyaratan uji normalitas, linearitas dan multikolinearitas sudah terpenuhi dan untuk mengetahui hubungan antara variabel bebas dengan variabel terikat maka dilakukan uji hipotesis. Penelitian ini menggunakan teknik analisis korelasi product moment dan korelasi ganda untuk mengetahui hubungan variabel bebas yaitu pemahaman sejarah nasional Indonesia $\left(\mathrm{X}_{1}\right)$, minat belajar sejarah $\left(\mathrm{X}_{2}\right)$ dan kesadaran sejarah $\left(\mathrm{X}_{3}\right)$ secara bersama-sama dengan variabel terikat sikap nasionalisme (Y).

Hasil pengujian korelasi product moment dirangkum dalam tabel 8.

Tabel 8. Hasil Pengujian Korelasi Product Moment

\begin{tabular}{ccccc}
\hline $\begin{array}{c}\text { Pemaham } \\
\text { an } \\
\text { Sejarah } \\
\text { Nasional }\end{array}$ & Minat & Kelajar & Sejarah & an \\
sejarah & $\begin{array}{c}\text { Nasio } \\
\text { Nalis } \\
\text { me }\end{array}$ \\
\multicolumn{2}{c}{ Indonesia } & & & \\
\hline$r$ & 1 & & & 0,503 \\
$P$ & & & & 0,000 \\
$r$ & & 1 & & 0,599 \\
$P$ & & & & 0,000 \\
$r$ & & & 1 & 0,662 \\
$P$ & & & & 0,000 \\
$r$ & 0,503 & 0,599 & 0,662 & 1 \\
$P$ & 0,000 & 0,000 & 0,000 & \\
\hline
\end{tabular}

Hasil pengujian korelasi ganda dirangkum dalam tabel 9.
Tabel 9. Hasil pengujian korelasi ganda

\begin{tabular}{|c|c|c|c|c|}
\hline $\begin{array}{c}\mathrm{M} \\
\mathrm{o} \\
\mathrm{de} \\
\mathrm{l}\end{array}$ & $\mathrm{R}$ & $\begin{array}{c}\text { S } \\
\text { squar } \\
\text { e }\end{array}$ & $\begin{array}{c}\text { Adjuste } \\
\text { d } \\
\text { Rsquar } \\
\text { e }\end{array}$ & $\begin{array}{l}\text { Std. } \\
\text { Error of } \\
\text { The } \\
\text { Estimat } \\
\text { e }\end{array}$ \\
\hline 1 & $\begin{array}{c}.780 \\
\mathrm{a}\end{array}$ & .608 & .599 & $\begin{array}{c}5.0796 \\
6\end{array}$ \\
\hline
\end{tabular}

\section{Pengujian hipotesis pertama}

Berdasarkan hasil pengujian korelasi product moment pemahaman sejarah nasional Indonesia dengan sikap nasionalisme didapatkan nilai rhitung sebesar 0,503 dengan p sebesar 0,000. Berdasarkan nilai $\mathrm{p}<0,05$, maka dapat disimpulkan ada hubungan yang positif antara pemahaman sejarah nasional Indonesia dengan sikap nasionalisme. Semakin baik pemahaman sejarah nasional Indonesia maka semakin baik pula sikap nasionalisme siswa.

Pengujian hipotesis kedua

Berdasarkan hasil pengujian korelasi product moment minat belajar sejarah dengan sikap nasionalisme didapatkan nilai rhitung sebesar 0,599 dengan $p$ sebesar 0,000. Berdasarkan nilai $\mathrm{p}<0,05$, maka dapat disimpulkan ada hubungan yang positif antara minat belajar sejarah dengan sikap nasionalisme. Semakin baik minat belajar sejarah maka semakin baik pula sikap nasionalisme siswa.

\section{Pengujian hipotesis ketiga}

Berdasarkan hasil pengujian korelasi product moment kesadaran sejarah dengan sikap nasionalisme didapatkan nilai rhitung sebesar 0,662 dengan $\mathrm{p}$ sebesar 0,000. Berdasarkan nilai $\mathrm{p}<0,05$, maka dapat disimpulkan ada hubungan yang positif antara kesadaran sejarah dengan sikap nasionalisme. Semakin baik kesadaran sejarah maka semakin baik pula sikap nasionalisme siswa. 
Pengujian hipotesis keempat

Berdasarkan hasil pengujian korelasi ganda antara pemahaman sejarah, minat belajar sejarah dan kesadaran sejarah secara bersama-sama dengan sikap nasionalisme didapatkan nilai rhitung sebesar 0,780 dengan $p$ sebesar 0,000. Berdasarkan nilai $p<0,05$, maka dapat disimpulkan ada hubungan yang positif antara pemahaman sejarah, minat belajar sejarah dan kesadaran sejarah secara bersama-sama dengan sikap nasionalisme.

Pengujian signifikansi hubungan pemahaman sejarah nasional Indonesia, minat belajar sejarah dan kesadaran sejarah terhadap sikap nasionalisme dilakukan menggunakan uji $\mathrm{F}$, sehingga

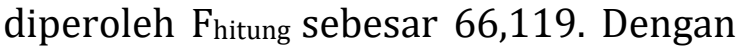
demikian, $F_{\text {hitung }}$ lebih besar dari $F_{\text {tabel }}$ (Fhitung 66,119 $>F_{\text {tabel }}$ 3,07). Hal tersebut menunjukkan bahwa terdapat hubungan yang signifikan antara pemahaman sejarah nasional Indonesia, minat belajar sejarah dan kesadaran sejarah dengan sikap nasionalisme.

$$
\text { Semakin baik pemahaman }
$$

sejarah, minat belajar sejarah dan kesadaran sejarah secara bersama-sama maka semakin baik pula sikap nasionalisme siswa.

\section{Pembahasan}

Pemahaman sejarah nasional Indonesia dengan sikap nasionalisme

Hasil penelitian didapatkan pemahaman sejarah nasional Indonesia mempunyai hubungan positif dan signifikan dengan sikap nasionalisme. Semakin baik pemahaman sejarah nasional Indonesia semakin baik pula sikap nasionalisme siswa, begitu juga sebaliknya semakin kurang pemahaman sejarah nasional Indonesia semakin berkurang pula sikap nasionalisme siswa.

Pemahaman adalah proses yang menjadikan suatu pengetahuan menjadi milik dirinya dan pada akhirnya akan mempengaruhi proses berpikir dan bertindak individu. Kemampuan memahami sangatlah penting untuk mencapai pengetahuan prosedur, yaitu untuk memahami arti atau konsep, situasi serta fakta yang diketahuinya (Arikunto, 2009: 18). Pendapat ini menjelaskan bahwa terdapat hubungan anatara pemahaman dengan sikap.

Tugiyono (2004: 5-6) yang memperjelas teori dari Arikunto mengenai hubungan pemahaman sejarah nasional Indonesia dengan sikap nasionalisme. Menurutnya menanamkan pemahaman tentang masa lampau bangsa Indonesia adalah salah satu tujuan dalam pembelajaran sejarah di sekolah. Siswa perlu diberikan pemahaman tentang sejarah bangsa Indonesia untuk menumbuhkan sikap nasionalisme melalui penghayatan nilai masa lampau bangsa kita.

Pemaknaan kembali nasionalisme melalui pemahaman sejarah yang dimaksud oleh Freire (2007:26) yaitu sejarah bersifat dialektis karena digunakan untuk membedakan antara kondisi sekarang yang given dan yang masih menyisakan kemungkinan untuk emansipasi. Kondisi yang given tersebut dalam kajian ini adalah kenyataan sejarah bahwa perjuangan adalah upaya mempertahankan nasionalisme, sedangkan upaya pemahaman sejarah yang pada akhirnya akan membawa pada pemaknaan kembali nasionalisme kebangsaan adalah kondisi aktual sikap kebangsaan. Pendidikan merupakan proses internalisasi nilai termasuk nilai nasionalisme, maka pemahaman merupakan salah satu aspek penting dari proses internalisasi nilai nasionalisme tersebut. Pemahaman sejarah dalam hal ini sejarah bangsa yang merupakan proses penanaman nasionalisme melalui penyadaran terhadap realita sejarah yang membentuk identitas kebangsaan. 
Minat belajar sejarah dengan sikap nasionalisme

Hasil penelitian didapatkan minat belajar sejarah mempunyai hubungan positif dan signifikan dengan sikap nasionalisme. Semakin baik minat belajar sejarah semakin baik pula sikap nasionalisme siswa, begitu juga sebaliknya semakin kurang minat belajar sejarah semakin berkurang pula sikap nasionalisme siswa.

Dengan adanya minat belajar sejarah dalam diri siswa, akan memberikan kemungkinan penelaahan lebih mendalam tentang makna sejarah yang terdapat dalam sekumpulan fakta sejarah dan akan memberikan andil pembentukan sikap nasionalisme siswa. Mengingat sikap nasionalisme merupakan suatu bentuk loyalitas tertinggi pada pemeliharaan hidup bangsa dan pengembangan potensi bangsa serta pencegahan segala bentuk yang membahayakan eksistensi bangsa.

Penelitian ini juga sesuai pendapat dari Shaleh (2009: 262) yang menjelaskan terdapat hubungan antara minat belajar sejarah dengan sikap nasionalisme. Hubungan yang dimaksudkan adalah bahwa minat dijelaskan sebagai suatu kecenderungan untuk memberikan perhatian dan bertindak terhadap orang, aktivitas atau situasi yang menjadi objek dari minat tersebut dengan disertai perasaan senang. Bertindak di sini dijelaskan sebagai sikap nasionalisme siswa.

Hal ini dikuatkan oleh pendapat dari Nursam (2008: 422) yang menjelaskan tujuan kurikulum pendidikan sejarah adalah mengembangkan siswa untuk memahami berbagai peristiwa sejarah di tanah air secara kritis dan cerdas, menjadikannya sebagai bagian dari memori dalam dirinya sebagai warisan bangsanya, dan menggunakan pemahaman tersebut untuk mengenal dan mengembangkan jati diri bangsa ke arah kehidupan kebangsaan yang positif. Tujuan dari pembelajaran sejarah adalah aspek nasionalisme. Sehingga siswa yang memahami pembelajaran sejarah akan memiliki minat yang tinggi pada pembelajaran sejarah memiliki sikap nasionalisme yang tinggi pula.

Kesadaran sejarah dengan sikap nasionalisme

Hasil penelitian didapatkan kesadaran sejarah mempunyai hubungan positif dan signifikan dengan sikap nasionalisme. Semakin baik kesadaran sejarah semakin baik pula sikap nasionalisme siswa, begitu juga sebaliknya semakin kurang kesadaran sejarah semakin berkurang pula sikap nasionalisme siswa.

Antara nasionalisme dengan kesadaran sejarah memiliki hubungan. Kadar sikap nasionalisme dalam diri seseorang akan mempengaruhi sikap kesadaran sejarahnya. Sebuah masyarakat yang memiliki sikap nasionalisme tinggi tentu akan diikuti dengan kesadaran sejarah yang tinggi, kesadaran akan masa lalu, kesadaran akan kesamaan nasib sebuah bangsa. Maka nasionalisme pada akhirnya akan menjadi pengingat bagi setiap orang bahwa refleksi kehidupan berbangsa tidak dapat ditinggalkan, agar kesalahankesalahan yang pernah terjadi dalam sejarah menjadi pembelajaran dan tidak pernah kembali terulang.

Penelitian ini sesuai dengan pendapat dari Latif (2011: 51) yang menjelaskan hubungan antara kesadaran sejarah dengan sikap nasionalisme. Hubungan tersebut yaitu memiliki kesadaran sejarah akan membuat sebuah bangsa tidak akan kehilangan nilai-nilai yang sangat dibutuhkan di mana pun dalam keadaan bagaimanapun. Nilai-nilai terebut ialah nasionalisme patriotisme demokratis dan lain sebagainya.

Hal ini sejalan dengan pendapat Kartodirdjo (Aman, 2009: 14) bahwa 
semangat nasionalisme tidak dapat ditumbuhkan tanpa kesadaran sejarah. Hal ini berarti bahwa kesadaran sejarah mempunyai hubungan yang positif dan signifikan dengan sikap nasionalisme sehingga apabila kesadaran sejarah tinggi maka sikap nasionalisme siswa juga akan semakin tinggi.

Mereka yang memiliki pemahaman tinggi tentang sejarah akan cenderung menyatakan sikap berdasarkan sistem kesadaran yang telah terbangun dalam proses memahami, sehingga secara otomatis akan memberikan kontribusi yang nyata terhadap sikap nasionalisme.

Hubungan pemahaman sejarah, minat belajar sejarah dan kesadaran sejarah dengan sikap nasionalisme

Hasil penelitian didapatkan pemahaman sejarah nasional Indonesia, minat belajar sejarah dan kesadaran sejarah secara bersama-sama mempunyai hubungan positif dan signifikan dengan sikap nasionalisme. Semakin baik pemahaman sejarah nasional Indonesia, minat belajar sejarah dan kesadaran sejarah semakin baik pula sikap nasionalisme siswa, begitu juga sebaliknya semakin kurang pemahaman sejarah nasional Indonesia, minat belajar dan sejarah kesadaran sejarah semakin berkurang pula sikap nasionalisme siswa.

Berdasarkan hasil penelitian bahwa pemahaman sejarah nasional Indonesia memiliki hubungan dengan sikap nasionalisme. Seperti yang dijelaskan oleh Aman (2009: 35) menyatakan materi sejarah mengandung nilai-nilai kepahlawanan, keteladanan, kepeloporan, patriotisme, nasionalisme, dan semangat pantang menyerah yang mendasari proses pembentukan watak dan kepribadian peserta didik; memuat khazanah mengenai peradaban bangsabangsa, termasuk peradaban bangsa Indonesia. Dalam pembelajaran sejarah memuat materi peradaban bangsa
Indonesia yang di dalamnya terdapat nilai-nilai yang mampu membentuk watak dan kepribadian siswa, salah satunya adalah nasionalisme. Sehingga siswa yang memiliki pemahaman sejarah nasional Indonesia yang akan memiliki sikap nasionalisme yang baik pula.

Selanjutnya pendapat dari Suryani (2013: 209) menjelaskan bahwa salah satu mata pelajaran yang memiliki muatan pendidikan karakter adalah sejarah. Mata pelajaran sejarah penuh dengan muatan-muatan karakter kebangsaan yang telah dicontohkan oleh pahlawan. Sehingga siswa yang memiliki minat belajar yang tinggi terhadap sejarah akan memiliki sikap nasionalisme yang tinggi pula karena muatan materi yang ada pada pembelajaran sejarah tersebut yang merujuk pada karakter kebangsaan. Sejalan dengan pendapat dari Ahmadi (2013: 151) bahwa minat mengandung unsur konasi yang merupakan perwujudan minat dari diri seseorang dalam bentuk kemauan dan hasrat untuk melakukan suatu kegiatan. Tujuan dari pembelajaran sejarah adalah aspek nasionalisme. Dikuatkan oleh pendapat dari Park (2013: 183) Siswa yang secara aktif terlibat dengan apa yang mereka pelajari cenderung lebih mengerti, belajar lebih, ingat lagi, nikmati lebih dan lebih bisa menghargai relevansi apa yang telah mereka pelajari, daripada siswa yang secara pasif menerima apa yang kita ajarkan kepada mereka.

Sehingga siswa yang memahami pembelajaran sejarah akan memiliki minat yang tinggi pada pembelajaran sejarah memiliki sikap nasionalisme yang tinggi pula karena memiliki perhatian lebih terhadap sesuatu materi yang disampaikan. Hal ini didukung oleh pendapat dari Slameto (2013: 180) yang menjelaskan minat sebagai suatu rasa lebih suka dan rasa keterikatan pada suatu hal atau aktivitas tanpa ada yang menyuruh. Pembelajaran sejarah mengandung muatan karakter. Ketika 
siswa memiliki minat belajar yang tinggi maka dia akan memahami materi yang terkandung di dalam pembelajaran tersebut. Dapat disimpulkan bahwa siswa yang memiliki minat belajar sejarah yang tinggi memiliki sikap nasionalisme yang tinggi pula.

Menurut hasil penelitian di atas terdapat hubungan yang positif dan signifikan antara kesadaran sejarah dengan sikap nasionalisme. Penelitian ini sesuai pendapat dari Aman (2009: 14) yang menjelaskan bahwa kesadaran sejarah amat esensial bagi pembentukan kepribadian. Pendidikan memiliki hubungan yang erat dalam proses pembentukan kesadaran sejarah. Dalam rangka nation building pembentukan solidaritas, inspirasi dan aspirasi mengambil peranan yang penting, di satu pihak untuk system-maintenance negara nasion, dan dipihak lain memperkuat orientasi atau tujuan negara tersebut.

Pendapat lain dari Garvey dan Mary Krug (Amiruddin, 2016: 199-200) menjelaskan bahwa ketika seseorang belajar sejarah seseorang akan mendapatkan ranah kognitif, afektif dan psikomotorik di dalam belajarnya. Hal ini dapat dihubungkan bahwa dengan belajar sejarah ketiga aspek tersebut jika dihayati lebih dalam bukan hanya deretan fakta, periode peristiwa, kritik karya, teknik dan menuliskannya. Tetapi juga nilai yang terkandung di dalam sebuah peristiwa sejarah yang begitu unik dengan konsep diakroniknya dapat menumbuhkan kesadaran sejarah, di sinilah digagas sebuah konsep kesadaran sejarah untuk pembentukan karakter bangsa. Karakter bangsa yang dimaksudkan di sini adalah termasuk sikap nasionalisme yang dimiliki oleh siswa.

\section{Simpulan dan Saran}

Simpulan

Ada hubungan yang positif dan signifikan antara pemahaman sejarah nasional Indonesia dengan sikap nasionalisme. Semakin baik pemahaman sejarah nasional Indonesia siswa semakin baik pula sikap nasionalisme siswa, begitu juga sebaliknya semakin buruk pemahaman sejarah nasional Indonesia semakin buruk pula sikap nasionalismenya.

Ada hubungan yang positif dan signifikan minat belajar sejarah dengan sikap nasionalisme. Semakin baik minat belajar siswa semakin baik pula sikap nasionalisme siswa, begitu juga sebaliknya semakin rendah minat belajar sejarah semakin rendah pula sikap nasionalismenya.

Ada hubungan yang positif dan signifikan antara kesadaran sejarah dengan sikap nasionalisme. Semakin baik kesadaran sejarah siswa semakin baik pula sikap nasionalisme siswa, begitu juga sebaliknya semakin buruk kesadaran sejarah semakin buruk pula sikap nasionalismenya.

Ada hubungan yang positif dan signifikan antara pemahaman sejarah nasional Indonesia, minat belajar sejarah dan kesadaran sejarah secara bersamasama dengan sikap nasionalisme. Semakin baik pemahaman sejarah nasional Indonesia, minat belajar sejarah dan kesadaran sejarah siswa semakin baik pula sikap nasionalisme siswa, begitu juga sebaliknya semakin buruk pemahaman sejarah nasional Indonesia, minat belajar sejarah dan kesadaran sejarah semakin buruk pula sikap nasionalismenya.

\section{Saran}

Berdasarkan kesimpulan dari hasil penelitian di atas maka dalam bagian ini disarankan dengan adanya hubungan yang positif dan signifikan antara pemahaman sejarah nasional Indonesia, minat belajar sejarah dan kesadaran sejarah dengan sikap nasionalisme dapat dijadikan sebagai bahan pertimbangan bagi guru untuk 
lebih memperhatikan sikap nasionalisme siswa yang didukung dengan pemahaman sejarah nasional Indonesia, minat belajar sejarah dan kesadaran sejarah pada saat menyampaikan materi di dalam kelas. Untuk siswa yang bersangkutan agar dapat meningkatkan pemahaman sejarah nasional Indonesia, minat belajar sejarah, kesadaran sejarah dan juga sikap nasionalisme sehingga bisa menjadi siswa yang memiliki nilai-nilai moral yang baik.

\section{Daftar Pustaka}

Ahmadi, A. (2013). Psikologi Umum. Jakarta: Rineka Cipta.

Aman. (2009). Evaluasi Pembelajaran Sejarah. Yogyakarta: Diktat FISE UNY.

Aman. (2009). Kesadaran Sejarah dan Nasionalisme: Pengalaman Indonesia. Jurnal Informasi, 2(2).

Aman. (2011). Model Evaluasi Pembelajaran Sejarah. Yogyakarta: Ombak.

Amiruddin. (Oktober 2016). Peran Pendidikan Sejarah Dalam Membangun Karakter Bangsa. Makalah disajidkan dalam Seminar Nasional Pendidikan Ilmu-Ilmu Sosial Membentuk Karakter Bangsa Dlam Rangka Daya Saing Global, Kerjasama: Fakultas Ilmu Sosial Universitas Negeri Makassar dan Himpunan Sarjana Pendidikan Ilmu-ilmu Sosial Indonesia

Arikunto, S. (2009). Dasar-dasar Evaluasi Pendidikan. Jakarta: Bumi Aksara.

Clark, A. (2014). Inheriting the past: Exploring historical consciousness across generations. Historical Encounters: A journal of historical consciousness, historical cultures, and history education, 1(1).

Freire, P. (2007). Politik Pendidikan, Kebudayaan, kekuasaan dan Pembebasan. Yogyakarta: Pustaka Pelajar.

Latif, Y. (2011). Negara paripurna. Jakarta: Gramedia pustaka utama.

Nursam, M., Baskara, T., Wardaya, S. J., Adam, A. (2008). Sejarah yang memihak, mengenang Sartono Kartodirjo. Yogyakarta: Ombak.

Park, C. (2013). Engaging Students in the Learning Process: the learning journal. Journal of Geography in Higher Education, 27(2).

Poesponegoro, M. D. \& Notosusanto, N. (2010). Sejarah Nasional Indonesia Jilid I- VI. Jakarta: Balai Pustaka.

Shaleh. A. R. (2009). Psikologi Suatu Pengantar Dalam Perspektif Islam. Jakarta: Prenada media.

Slameto. (2013). Belajar dan Faktorfaktor yang Mempengaruhinya. Jakarta: Rieneka Cipta.

Soewarsono. (2011). Beberapa Acuan Untuk Membaca Ikatan Budaya dan Nasionalisme Indonesia Melalui Perspektif Regional atau Kedaerahan. Dalam Thung Ju Lan dan M. Azzam Manan (Ed) Nasionalisme dan Ketahanan Budaya di Indonesia Sebuah Tantangan. Jakarta: LIPI Press. 90-106.

Sudarsono, J. (2011). Isi Ulang KeIndonesiaan: Strategi Memperkokoh Nasionalisme dan Ketahanan Budaya Indonesia. Dalam Thung Ju Lan dan M. Azzam Manan (Ed) Nasionalisme 
dan Ketahanan Budaya di Indonesia Sebuah Tantangan. Jakarta: LIPI Press. v-ix.

Suharyat, Y. (2009). Hubungan antara sikap, minat dan perilaku manusia. Jurnal REGION, 1(2).

Suryani, N. (2013). Pengembangan model internalisasi nilai karakter dalam pembelajaran sejarah melalui model value clarification technique. Jurnal Paramita, 23(2).

Tugiyono, K. S. (2004). Sejarah. Jakarta: Grasindo.

Zhang, Y. (2014). Analyzing the Connotation of Mao Zedong's Nationalism. International Journal of Social Science Studies, Vol 2(1). 